https://helda.helsinki.fi

\title{
The dialectics of agency in educational ethnography
}

\section{Rainio, Anna}

2017

Rainio , A \& Hilppö , J 2017 , ' The dialectics of agency in educational ethnography ' , Ethnography and Education, vol. 12 , no. 1 , pp. 78-94 . https://doi.org/10.1080/17457823.2016.1159971

http://hdl.handle.net/10138/308669

https://doi.org/10.1080/17457823.2016.1159971

unspecified

acceptedVersion

Downloaded from Helda, University of Helsinki institutional repository.

This is an electronic reprint of the original article.

This reprint may differ from the original in pagination and typographic detail.

Please cite the original version. 
Manuscript submission to Ethnography and Education:

\section{The dialectics of agency in educational ethnography}

Anna Pauliina Rainio (corresponding author)

University Lecturer

Department of Teacher Education

P. O. Box 9, 00014 University of Helsinki, Finland anna.rainio@ helsinki.fi

$+358503180306$

Jaakko Hilppö

$\mathrm{PhD}$ Student

Department of Teacher Education

P. O. Box 9, 00014 University of Helsinki, Finland jaakko.hilppo@helsinki.fi

$+358405334643$ 


\begin{abstract}
This paper outlines a dialectical conceptualization of children's agency for the purposes of multidisciplinary educational theory and practice. We will illuminate the following five contradictory but connected dimensions of children's agency, or the dialectics of agency, identified from recent theoretical debates: Agency as (1) enacted and imagined; (2) as situatively emergent and progressively developmental; (3) as dependence and separation; (4) as mastery and submission; and (5) as control and freedom.

We examine and discuss these contradictions "at work" in an ethnographic early education case study. Our argument is that the children's struggles towards agency and adults' efforts and failures to support children in their struggles, can be conceptualized as a dialectical movement between the opposing poles of these contradictions. Our dialectical reading of both data and theory has helped us to highlight the challenges the practitioners face when supporting children's agency and the solutions they implement when doing so.
\end{abstract}

Keywords: children's agency, contradiction, dialectics, educational ethnography, playworld 


\section{Introduction}

A key aim of ethnographic research is to capture phenomena in all their fullness and complexity. Ethnographers are at the same time called to conceptualize and theorize the phenomena they study and engage in discussion with previous studies (O'Reilly, 2012; Hammersley \& Atkinson, 2007). However, conceptualizing this empirical complexity without reverting to a singular reading of the studied phenomena remains a challenging task for any educational ethnographer. In this article we discuss this challenge in our ethnographic work with children's agency in educational settings.

The question of how to foster children who are responsible, reflective and critical is a central and recurring educational concern. The import of agency is also mirrored in the current ethnographic educational research literature, in which children's agency is increasingly topicalized (i.e. Ayton, 2012; Huf, 2013). On a general level, agency refers to human beings' capacity to impact and eventually (collectively) transform their life circumstances and the practices in which they are engaged (cf. Hofmann \& Rainio, 2007). However, agency is a complex concept which has been conceptualized in very different, even contradictory ways in different research traditions. On the one hand, agency is a process of interaction with material resources, social institutions and the collective efforts of individuals. On the other hand, individual efforts and individuals' understanding of themselves as agentive can be seen as crucial for agency to become possible (Davies, 1990).

Simply adopting conceptualizations of agency from neighboring research traditions runs the risk of unproductive empirical reductions of the educational reality. Therefore, in this study we apply a multidisciplinary reading of the concept. From the theories on agency, we draw from sociocultural and activity theory perspectives (i.e., Vygotsky, 1978), critical psychology (Holzkamp, 1991), sociology of childhood (Lee, 2005; Prout, 2005), poststructuralist and feminist research (e.g., St. Pierre, 2000) and naturalistic social theory (e.g., Barnes, 2000). Our interest is not to enter the debate on the nature and possibility of human agency in principle, but on the ways human agency becomes possible for different individuals, particularly for pupils in educational settings. 
In order to use these multiple but contradictory theories in an empirical analysis, we will need a framework that conceptualizes and takes seriously the contradictory nature of phenomena. To this end, we have been informed by the dialectical tradition within which facing and resolving contradictions is at the core of human development (Tolman 1981; Engeström, 1996). This dialectical conceptualization was originally introduced by Rainio (2010), and we will further develop, clarify and reiterate it in this paper. Therefore, instead of trying to avoid a contradictory reading of both data and theory, we try to embrace the contradictions and their developmental potential both in data as well as in theory. We will introduce a case study of two seven-year-old girls, Helen and Sara, whose struggles for agency we follow and interpret in a play pedagogical setting called a playworld. Through this case study we will show how a singular theoretical reading of agency would not fully grasp children's and adult's struggles for agency in mundane educational interactions.

\section{The framework of dialectical logic}

In the social sciences, contradictions are interpreted differently depending on the overarching background ideology. According to classical analytical logic, contradictions, antinomies or paradoxes reflect the inherent weakness of the theory and its reasoning (Sainsbury, 1995). An antinomy is born when two valid arguments lead to contradictory conclusions. Accordingly, the contradictions or dialectical dimensions of agency outlined in this paper could be dismissed simply by viewing them as paradigmatic differences; tensions spring up naturally, as agency is a concept used in various paradigms. Different disciplines and paradigms have different histories of, interests in and viewpoints into human causation. By keeping the paradigms separate, we avoid contradictory conclusions. However, in the educational sciences, as well as in the ethnographic research tradition, central research concerns and phenomena require scholars to espouse a multidisciplinary stance, and working with multiple paradigms is often the starting point. It thus stands to reason that the aforementioned contradictions emerge, in some form or another, when we embark to investigate agency in empirical educational settings.

In this article, we will employ a dialectic conceptualization of contradictions. The roots of dialectics stem from the founding philosophical work of Hegel (1969) and Marx (1973), where the emergence of contradictions in societal activity has a specific logic. Moreover, the 
acknowledgement and successful mastery of the contradictions prevalent in everyday life are understood as driving forces of development and change (e.g., Engeström, 1987; Glassman, 2000). We will use this idea of contradictions as growth points as a starting point for our work.

From this dialectical perspective, the five dialectical dimensions of agency outlined in this article can be understood as ontological, or internal, contradictions of agency, with each dimension characterizing its individual aspects. These internal contradictions then manifest as challenges or tensions in practical educational activities. Although the challenges and tensions can be solved, the underlying contradiction remains "at the core" of the phenomenon (e.g., Goulart \& Roth, 2010). In this fashion, contradictions, or better their manifestation as tensions and challenges (Engeström \& Sannino, 2011), reflect the present historical moment of their emergence.

To conclude, the contradictions of agency that we have recognized in our ethnographic work as well as in the theoretical literature are not for us problems that should be overcome or avoided. Instead, we will try to depict how moving between the opposing poles of these dimensions actually constitutes the phenomenon that we study. This will help us understand the challenges faced and the solutions implemented by practitioners in the field. Through this reading, our aim is to overcome a dichotomous and static reading of agency and instead treat agency as a living and evolving phenomenon.

\section{The Ethnography of the Brothers Lionheart Playworld}

In discussing the contradictions inherent in the concept of agency - and in becoming visible for the ethnographer conducting field work - we will use examples from an ethnographic study of a play pedagogical setting called a playworld. In the playworld, pupils and teachers explore different phenomena through taking on the roles of characters from a story and acting inside the frames of an improvised plot. The pedagogy is based on Gunilla Lindqvist's (1995) aesthetic play theory and Pentti Hakkarainen's (i.e., 2004; 2008) narrative learning theory. Rainio (2010) conducted her ethnographic study in a Finnish mixed-age elementary school classroom in the school year 2003-2004. She followed the class, which took a dramatized journey inspired by the original story of the Brothers Lionheart, acting as villagers from Cherry Valley on their way to rescue the neighboring Wild Rose Valley from the hands of the evil Tengil. The children and teachers engaged in this activity weekly for five months, acting in roles and changing their 
classroom into the world of the story. Video data was collected from the playworld activities and the weekly planning and evaluation sessions with the teachers. The focus was on individual students and their developing possibilities for agency in their participation in the creation of the playworld.

The playworld pedagogy (and an ethnographic study of it) makes visible the contradictions of agency discussed in this paper and allows their exploration in an educational context. Further, the playworld is a particularly interesting field of study for student agency as it aimed to provide a transitional and dialogical space in which both adults and children were forced to develop and assess their ways of acting and being together (Rainio, 2010). However, at the same time the study of the playworld showed that the playworld pedagogy, which explicitly aimed at developing children's agency and collaboration, also contained several constraining elements. In this article we will refer to the case of Helen and Sara, two seven-year-old girls, and their participation in the playworld as an example of how the attempts to ensure and advance children's agency in the classroom were complex and contradictory, not only for the teachers, but also for the children themselves, as well as for the researcher who tried to recognize these agentive efforts (for the original analysis of Helen and Sara's case, see Rainio, 2009).

\section{The dialectics between enacted agency and imagined agency}

One of the central challenges that we faced as ethnographers researching children's agency was whether to lean mostly on what is visible or also on the thoughts, dreams and ideas of the participants. As a concept, agency easily leads us to focus explicitly on the visible, active and productive action in the material world. However, a disposition to dream, improvise and imagine alternative ways and worlds, "to formulate other social scenes in imagination" (Holland et al., 1998, p. 236), is also a crucial element of agency. The fact that this element is not visible in practical and productive action makes it harder to grasp in an empirical study, particularly when related to children (cf. Rainio, 2009). This is a challenge that requires the educator or parent to reflect on her or his efforts in fostering children's agency and to make decisions based on this reflection. It is far easier to recognize and support a child who is active and participatory than a child who withdraws, is passive or spends time in her or his own thoughts. One needs to be specifically sensitive in order to grasp the whole of agency, both as enacted as well as imagined. 
This movement between enacted and imagined agency was visible in our case study of Helen and Sara. In the Brothers Lionheart playworld, Helen and Sara took on the roles of the horses Grimm and Fyalar, powerful figures in Astrid Lindgren's original story. Horses and riding were an important part of these girls' free time. The playworld inspired the girls to create their own horse play in the class. However, the fact that horses do not speak and the pedagogical organization of the small group work in the class (see Rainio, 2009) made it hard for these girls to contribute to the construction of the common playworld plot from their "horse positions." The girls' reaction to this disregard of their horse roles was to turn inwards and distance themselves from the class activity (cf. 'restrictive agency' Holzkamp, 1991). In a sense, the girls turned to their imagination to create alternative realities, imagined "figured worlds" where they could become agentive on their own terms (Holland et al., 1998). These private worlds took place on the sidelines of the collective playworld activity but were related to it and inspired by it. These micro-worlds, however, also isolated Helen and Sara as they were not acknowledged nor supported by others.

As the year progressed, Helen started actively resisting the prevailing situation by generalizing (cf. Holzkamp, 1991) about the way girls and boys were treated in the playworld activity. For example, by acknowledging gender as an issue, Helen, along with a couple of other girls, complained to the teachers that boys were given more tasks and more central roles in the playworld. In this way the girls finally made others - the teachers - react to them. In response, the adults arranged an episode with the dragon Katla in which the girls played a central role within the playworld plot. In terms of critical psychology, the girls' actions can be interpreted as a development of generalized agency (Holzkamp, 1991), in which the girls questioned the takenfor-granted gender categories and used them as a tool to first assess their relation to the world and the possibilities that this relation offers, and then secondly to extend these possibilities (Tolman, 1994). In short, the girls had agency in breaking away from the gendered and restricting categorizations of the playworld.

Yet, if only this active and transformative action is taken as agency, as theories of agency focusing on active participation in shared activities would have us do (compare the "competent child" discourse, see i.e. Ayton, 2012), a large part of Helen's and Sara's agency in the 
playworld would have been left out of the researcher's scope. Sara, for example, talked about her various fictive roles ("Happi, Volur, Tomppa") and their adventures in the story at the end of the playworld when she was interviewed, and none of these roles were visible in the observed video data nor known to her teachers. Rainio (2009) suggests that it was the private, inward-turning play activity that gave Helen and Sara not only joy but also the courage and self-awareness necessary to extend their possibilities for action by articulating to others how constrained the playworld was for them. Thus, to understand the development of these two girls' agency in the playworld, it was essential to capture this dialectical movement between these two different end points of agency: from turning inward and developing alternative realities in one's imagination ("restrictive" agency according to Holzkamp) to actually materially impacting and changing the existing situation ("generalized" agency). The ethnographic method with its desire to capture the complexity in the field makes this possible, but requires both very detailed analysis as well as longer time scales.

\section{The dialectics between situative emergence and the progressive development of agency}

Another challenge for us ethnographers trying to capture agency in real life events was whether to see agency as something continuous and enduring (the developmental or psychological view) or rather as situational and contingent (the post-structural view). This central divide also appears in the literature. As is often taken up by post-structural theorists, the possibility to act agentically requires a subject position (e.g., Davies, 1990, see also Ayton, 2012). In this sense agency is related to the local and changing social, material and discursive conditions surrounding us. But agency also requires understanding oneself as someone capable of acting in and transforming the taken-for-granted assumptions of the ways the world is organized and of one's own stance in this world (cf. Hofmann, 2008). To conceive of oneself as an agent whose actions count requires experience, learning and development. Therefore we argue that to understand children's agency in educational settings, we will need to see agency both as an emergent capacity of the developing person as well as a characteristic of interpersonal interaction (cf. Martin 2004). Helen's and Sara's case exemplifies this.

As explained above, Helen and Sara had often stayed in the background of the playworld, and as a result the researcher had not initially paid much attention to their actions. However, by the end 
of the year, her interest in understanding Helen and Sara's agency was sparked by a surprising episode in the data. When viewing the recorded video material, Rainio noticed an episode in which Helen tried to enter the boys' play with the new and improvised role of a "horse soldier" (see more in Section 7). As the researcher started to analyze the episode more closely, it became apparent that without locating the episode within the wider stream of actions in the playworld, it would have not made sense. All the recorded material on Helen and Sara needed to be taken into account in order to see how they were positioned and categorized by others, how adults and other children talked about them, how the girls responded, and how this interaction influenced the shape of the playworld events themselves along a longer time scale. That is, to understand Helen and Sara's agency in the playworld, the researcher crafted an interpretive narrative of the different but sequentially related situational manifestations of agency in the playworld interaction and their development over time. Only this dialectical ethnographic work of following both the developmental trajectory of the girls' participation in the playworld over five months and the micro-interaction in certain playworld episodes revealed the complexity of these children's agency and helped to avoid a flat and simplistic interpretation of these girls' agency in the playworld.

In line with childhood studies (see Lee, 2005; Prout 2005), we argue that when researching agency ethnographically, the situatively emergent (sociological) and the temporarily developing (psychological) views, which in literature often oppose each other, should be dialectically combined. Ethnographic data should be analyzed on these two levels simultaneously: (a) on the level of micro-interaction where the social reality is situationally constructed and (b) on the developmental level to grasp the continuity and development of these situational manifestations of agency (cf. Rainio, 2007).

\section{The dialectics between dependence and separation}

A third very vivid contradiction that we recognized in Helen and Sara's agency within the playworld took place between the need for belonging and the need for being independent. Helen and Sara clearly longed for recognition from others in the playworld activity and felt bad when this was not the case. At the same time, their need for their own, independently created play in which they were the main actors and agents started to isolate them from other children. This can 
be exemplified with a case in which Helen and Sara had organized a small play for other children. They decided to act it out in a stall they had built under a table, which was a central location of their horse activities. However, their play under the table was very private and hard to follow, although it had been meant as a public performance. The other children soon lost interest and this greatly upset the girls. The girls' needs for simultaneous privacy and recognition contradicted each other. However, for a sense of agency, both were needed: agency is both belonging to a community and separating from it.

This contradiction between the dependent and separate individual can also be recognized in the literature about agency. Barnes (2000) argues that this contradiction actually stems from the fact that we do not take the idea of individual agency as a social status that is artificially distributed between people, but often as a state of being human. The idea of the independent and responsible individual is an important means through which a collective manifests its agency and creates institutional stability and order. This however has created fundamental problems related to the illusion of a detached and separable individual (see Lee, 2005). The fact that we treat each other as independent and responsible individuals does not mean that we are such on an ontological level. Therefore, many researchers have started to conceptualize the context-dependent, relational and distributed nature of agency: human agency is a "hybrid" that can be understood only as a relation between different entities.

Interestingly, highlighting the collective aspect of agency almost exclusively leaves aside the question of the access of different individuals to the practices of this collective agency. In such a view, agency becomes a matter limited to those who are already accredited as responsible agents and are thus already involved in the process of this distributed, social agency (Rainio, 2010). Historically, groups that are not given the status of being responsible members of society have included, for instance, children (Davies, 1990; 2006; Lee, 2005). These groups have been considered to be irresponsible for their own actions and thus also outside of the collective agency. If we want to understand the question of agency as a complex phenomenon, we need to take such marginal and excluded groups and their struggle for agency into account in a way that does not imply a detached and individualistic but a relational and context-dependent view. 
Here, a conceptual clarification made by Lee (2005) is useful. He distinguishes the concepts of separateness and separability. Lee shows convincingly how it is necessary in terms of dignity and human rights that we can be taken as persons separable from each other, but not as totally independent and separate from each other. In this way the unfruitful opposition between dependence vs. separateness turns into a question of separability and its functions in different social situations. Now, as ethnographers we claim that it is this dialectical dynamics and struggle for balance between dependence and separation that makes educational settings and learning and development so interesting. Further, the pedagogical relationship (i.e., between teacher and pupil) can be examined from this perspective: interesting in it is the movement between belonging and being independent and separate, and agency requires them both (Gillespie, 2012). Teachers, parents, administrators and children themselves need to define and negotiate in which situations children can be taken as responsible and in which not, and in what way not being taken as responsible for one's actions limits or does not limit how much one is heard and has a say in the activity that one is a part of. For an ethnographer who is trying to understand and depict the development of children's agency in educational settings, this dialectics cannot be overlooked. In Helen and Sara's case, this dialectical movement constituted their agency. It was one of their central struggles in the playworld, one in which they would have needed more support. Helen's desire to belong and to find a more recognized position in the stream of the playworld activities led to the creative invention of a new character: the Horse Soldier. This role opened up for us a new layer in the dialectics of agency within the playworld, namely between mastery and submission. We will discuss this contradiction in agency next.

\section{The dialectics between mastery and submission}

Being an agentive member of a community, or society in general, often means taking part in renewing and developing the practices, traditions and laws of that particular community. Yet, in order to do this, these same traditions and laws have to be learned and internalized before they can be renewed. That is, from a cultural psychological perspective (e.g. Wertsch et al., 1996 PUUTTUU LÄHTEISTÄ), having agency to renew and transform a particular community or a culture means also taking the time to learn and adopt the practices, tools and conceptualizations 
of that particular culture. This makes social life and human development inherently and necessarily contradictory and dialectical. A similar contradiction seems to characterize poststructuralism's subject, which as St. Pierre explains, is:

a subject that exhibits agency as it constructs itself by taking up available discourses and cultural practices and a subject that, at the same time, is subjected, forced into subjectivity by those same discourses and practices. (St. Pierre, 2000, p. 502)

Thus, in order to have the agency to to modify, alter or resist existing structures and discourses, a subject also needs to subject to these discourses to a certain degree. The emergence of Helen's improvised "horse soldier" character is a clear example of this dialectical dance between what we call mastery and submission. Just before the emergence of the "horse soldier" character, Helen is sitting at a table with a group of girls preparing costumes for horses. At the same time, a group of boys is playing loudly in the corridor close to the girls" table. Their "battle" is a continuation of a scene from the story that they had just dramatized together with their teacher. The teachers have earlier established this small group of boys to let the less loud and less wild boys of the class (who, however, had chosen these soldier characters) to safely experience alternative positions and ways of being through playing the "bad guys" in the group. The same kind of need had not been suggested for any of the girls; instead, it was considered that the girls "know what they are doing." While Helen is sitting at the table, the following interaction ensues.

Data excerpt 1 .

1. Helen: (Sits at the table, preparing the mane for her horse role, and says to Ella) A horse is ridiculous without ears! Your horse doesn't have ears.

2. (Ella does not comment.)

3. Helen: (Rises from the chair, takes the mane and starts galloping on her knees shouting): The horse soldier, koppoti koppoti, the horse soldier!

4. Andy: (Comes and notices Helen. He shouts): Sam come see Helen! (Andy turns back to Helen): Helen, do it again, do it again please! You know, the way you did.

5. (Sam and Mikael come to follow as Helen gallops as a horse soldier.)

6. (Andy is delighted and jumps up and down.) 
7. (The teacher calls the boys, and Sam and Mikael go to her.)

8. (Helen gallops to another room.)

9. Andy: (Goes to the teacher, T3) Tina, Tina, Helen is acting as a horse soldier!

10. (The teacher is working with somebody and does not pay attention to Andy's words.)

11. (Andy leaves the room.)

12. Helen: (Turns to the table and says to Ina and Ella) Now I got to make this look like a horse soldier. I AM a horse soldier. I looked good, didn’t I? ...I looked like a horse soldier (she also looks at the camera when saying this).

13. (Girls listen but do not comment.)

14. (Helen starts to work with the ears for the horse.)

In the above episode Helen expands her role as a horse with the help of the costume she is preparing. The invented horse soldier character reveals that she has quite cleverly mastered the valued and available discourses in the class/playworld. At the same time, in order to master these discourses she also needs to submit to them, to accept their gendered order. Turning her (femininely interpreted) horse role into a more masculine horse soldier role might give her a new possibility to join the more interesting play of the boys in the corridor. Later in this episode Helen actually tries to become involved in the battle play in the corridor through her new horse soldier role. She neighs and gallops to Andy, grabs a horn (an important artifact in the boys' play) and offers it to Andy. In this way she reciprocally notices Andy in the way Andy has noticed her earlier. Unfortunately, Andy is no longer paying attention to Helen's actions. Soon another pupil, Emil, from the group notices Helen's presence and tells her that "this isn't your game." This makes Helen leave the play activity immediately.

In the original analysis of the event, Rainio (2009) interpreted Helen's actions as, with the help of her just invented and improvised role of a "horse soldier," an attempt to escape the unsatisfying small group situation. In this role she tried not to abandon but to combine the two worlds, that of horses and soldiers (of which a soldier seemed to be more valued in the playworld). This required a simultaneous mastery as well as submission to the available discourses and practices in the class. 
We claim that for an ethnographer who is trying to grasp the living and moving (not static and dichotomic) emergence of children's agency, this dialectical dance between mastery and submission is important. As Davies (1990) has claimed, the question is not whether individuals can be said in any absolute sense to have or not have agency, but whether or not there is "awareness of the constitutive force of discursive practices and the means for resisting or changing unacceptable practices" (ibid., p. 359). Helen had clearly mastered the available discourses and resources and also used them very creatively. At the same time, she had to submit to stereotypical and gendered practices and interpretations. Helen also lacked the social resources (cf. Davies 1990) to make herself be taken seriously and supported. The world of "horses" and the world of "Tengil's soldiers" were not neutral but very gendered, as Helen soon realized when she was excluded by another pupil. Exclusion from agency may occur through the social categories that pre-exist the processes of positioning, as we saw in this case. Moreover, the teachers' pedagogical organization of the classroom work closed her off from participation. But when looked at from a longer time perspective, Helen (with several other girls) turned this confining category of gender into a tool through which they made needed changes to the pedagogical and practical organization of the playworld by the teachers. The dialectics of submission and mastery produced a new form of agency for Helen.

\section{The dialectics between control and freedom}

In the previous section we described the dialectics of agency between mastery and submission from the agent's (Helen's) point of view. In this section we will describe this dialectics from the point of view of a pedagogue or a pedagogical relationship. In the end, our ethnographic interest is in the process through which children's agency becomes possible and is supported in the daily activities in the classroom. In this the teacher's role must also be examined.

The case of Helen and Sara has shown us that very small children can master different discourses and practices and navigate in them to find their place in the stream of classroom events. In the playworld data, Helen and Sara "dance" very vividly within the dialectics of their agency making, but what they seem to lack is concrete support and recognition, particularly from their teachers. Although the adults in this particular playworld were very sensitive to children's 
agency and set the children's wellbeing and initiatives as a starting point in the project, they still seemed to be limited by certain gendered interpretations of Helen and Sara's horse roles, and thus failed to support the girls in their struggle for recognition. We will interpret this contradiction (following Rainio, 2010) by what we have called the dialectics between control and agency - and this is the fifth dialectical dimension of agency that we introduce in this article. This contradiction between control and agency has been conceptualized in many different ways in educational theory, starting from Immanuel Kant in the 18th century:

One of the greatest problems in education is how subjection to lawful constraint can be combined with the ability to make use of one's freedom. For constraint is necessary. How shall I cultivate freedom under conditions of compulsion? I ought to accustom my pupil to tolerate constraint upon his freedom, and at the same time lead him to make good use of his freedom. (Kant, On Education, 1803)

This contradiction has been called a paradox of pedagogy or an educational antinomy, dilemma or practical contradiction of schooling. However, it has been rarely treated dialectically. The contradiction lies in the conditional and imbalanced nature of the adult-child relation: although the endpoint of education is the ability for agency and even when education explicitly aims at embracing the child's freedom in its practices, a pedagogical relationship always presupposes some form of coercion from the part of the adult. At the very least, prescribing agency as an endpoint for education undermines the agency of the child in the present. In educational practice this contradiction appears as a simultaneous need for control and order and for the promotion of individual students' involvement and personal desires (see McNeil, 1986). In different historical times we have solved this contradiction in practice in different ways. The contradiction is also reflected in the long-term contestation between child-centered or progressive methods and more traditional authoritative views on learning and schooling. Lately in Finnish discussions about schooling, this contradiction between control and agency has been seen as a central obstacle for classroom development and as impossible to overcome (see i.e., Salminen, 2012).

In this article we claim, based on Rainio (2010), that the playworld intervention can be interpreted as an effort to solve or deal with this contradiction on a very practical everyday level. 
In the following example, one of the participating teachers reflects on this momentary resolution of the contradiction in her own work in the playworld:

Data excerpt 2: Teacher interview, 22.3.2006

Teacher: Being in character, with pedagogical awareness and a reflective touch there in the background all the time, well you cannot compare it to any other method. I mean many activities feel good, there are many very nice methods that I like, but the feeling here is completely different. Essential is that you are not the authority figure then, but more on the level of the child's imagination [...] In those moments I feel that all formal matters fade away, all those things that disturb learning or make it a mere duty.

One of the objectives set by the teachers in the playworld pedagogy was to offer the children, through the playworld, wider possibilities for agency (i.e., inviting pupils to join in the planning and implementing of the playworld). However, ensuring the children's (and the teacher's) freedom in the playworld meant that it was simultaneously more difficult to ensure that all the children were heard and recognized, or that everyone found meaningful and satisfying positions in the playworld. Further, we argue that the pedagogical objective of creating a playworld that would particularly motivate and reach the most restless boys of the class meant that other, less visible and less active children were not given as much recognition (Rainio, 2010). On the other hand, it was this open-ended quality of the playworld that invited pupils such as Helen and Sara to develop their own very motivating horse play within the playworld - although it also simultaneously limited their possibilities.

This, we suspect, is very typical in a classroom with as many different needs and desires as there are students. However, it would be important for practitioners to become conscious of such contradictions affecting their work. The playworld made this contradiction visible and negotiable.

To conclude, freedom and control are not in opposition but part of the same phenomenon. They are both needed in the realization of agency, although they momentarily contradict each other. When they contradict, something new is always born. In the playworld this dialectical movement 
became visible, because the activity was open ended and invited several different ways of participation, both for adults and for children. Perhaps what we are trying to say with our dialectical conceptualization of agency is that whenever a teacher, a parent or a pedagogue develops structures (such as a playworld) that aim to support and further children's agency, they must always also accept and acknowledge that this same structure creates new limits and boundaries for agency that cannot be controlled. For a researcher interested in this dialectics, depicting this movement is key.

\section{Conclusions}

Researching and conceptualizing educational phenomena without reducing their complexity to any particular theoretical reading is a challenging endeavor. Whilst a particular theoretical perspective provides coherence and clarity, it at the same time runs the risk of overshadowing other contributing or contrasting perspectives, and thus might prevent the researcher from understanding the phenomena under study in all its fullness. Employing multiple theoretical perspectives would then seem to be a wise course of action, but one which leaves open how to reconcile the differences, or even contradictions, of the respective perspectives. The phenomenon of agency is especially intriguing in this regard, given its position as a boundary concept between historically dissenting disciplines such as sociology, psychology and education (see Prout, 2005).

In this paper, we have discussed this challenge in the context of our own work on researching children's agency in educational settings. We have also offered a dialectical understanding of contradictions and their relevance for educational ethnography as a potential solution to this problem. In short, we have identified five dialectical contradictions regarding children's agency. We have examined how the children and adults in our playworld case move or, better, dance between the opposing poles of these contradictions while they seek agentive positions and struggle for recognition. For an ethnographer, the challenge is to capture and conceptualize this dance. Table 1 below summarizes our findings and the implications for ethnographic practice.

[INSERT TABLE 1 HERE]

In dialectics, contradictions are understood as underlying practical activities, and thus they 
manifest differently as tensions and challenges in local practice (Engeström \& Sannino, 2011). The five contradictions of agency that we have presented in this paper should therefore be understood more as representing the dynamics of agency that practitioners in the field and researchers in their theoretical work must deal with, rather than viewing them as opposing theoretical perspectives of which one must be chosen over the other. That is, the ways in which these contradictions manifest in different pedagogical and educational situations, if at all, and how people face and solve these tensions in their daily life should be a matter of new empirical investigations. In our own work, we have begun to address this question by analyzing interactions between teachers and pupils in other educational settings (Rajala, Kumpulainen, Lipponen, Rainio, \& Hilppö, submitted PUUTTUU LÄHTEISTÄ; Ferholt \& Rainio, submitted).

Furthermore, given the limited range of our current empirical work, other possible dialectical dimensions relating to children's agency could be identified and conceptualized in other educational settings, and the ones we have recognized here could be contested.

The identification of these (or other) contradictions has also a potential bearing on educational practice and teachers' work. For example, without recognizing how the contradiction between control and agency manifests in their work, the day-to-day work of teachers can be very frustrating and potentially lessen their interest in developing their practice. The contradictions of agency can thus aid in conceptualizing the simultaneous and overlapping requirements to both maintain control and be responsible adults and to further children's independence and creativity. Analyzing and recognizing that the roots of such frustrations lie in central ontological contradictions inherent in the pedagogical relationship may help educators to see the manifestations of these contradictions as having developmental potential regarding their practice.

\section{References}

Ayton, K. (2012) Differing pupil agency in the face of adult positioning. Ethnography and Education, 7/1, 127-141.

Barnes, B. (2000). Understanding agency. Social theory and responsible action. London: Sage Publications.

Davies, B. (1990). Agency as a form of discursive practice. A classroom scene observed. British Journal of Sociology of Education, 11(3), 341-361. 
Davies, B. (2006). Subjectification: The relevance of Butler's analysis for education. British Journal of Sociology of Education, 27(4), 425-438.

Engeström, Y. (1987). Learning by expanding. An activity-theoretical approach to developmental research. Helsinki: Orienta-Konsultit.

Engeström, Y. (1996). Development as breaking away and opening up: A challenge to Vygotsky and Piaget. Swiss Journal of Psychology, 55, 126-132.

Engeström, Y., \& Sannino, A. (2010). Studies of expansive learning: Foundations, findings and future challenges. Educational Research Review, 5(1), 1-24.

Ferholt, B. \& Rainio, A. P. (Submitted / 2015). Enhancing early childhood student engagement through embracing ambivalence in playworlds: If I did not include all of the children in my classroom, "I might as well have stayed home." Submitted to Early Years.

Gillespie, A. (2012). Position exchange: The social development of agency. New ideas in psychology, 30(1), 32-46.

Glassman, M. (2000) Negotiation through history: dialectics and human development. New Ideas in psychology $18,1-22$.

Goulart, M. I. M., \& Roth, W. M. (2010). Engaging young children in collective curriculum design. Cultural Studies of Science Education, 5(3), 533-562.

Hakkarainen, P. (2004). Narrative learning in the fifth dimension. Outlines. Critical Practice Studies, 6(1), 5-20.

Hakkarainen, P. (2008). The challenges and possibilities of a narrative learning approach in the Finnish early childhood education system. International Journal of Educational Research, 47(5), 292-300.

Hammersley, M. \& Atkinson, P. (2007). Ethnography: Principles in practice. Third edition. London: Routledge.

Hegel, G. (1969). Hegel's Science of Logic. London: Allen \& Unwin.

Hilppö, J., Lipponen, L., Kumpulainen, K., \& Rajala, A. (2014). Visual artifacts as mediational means. A methodological investigation. Submitted to Childhood TÄHÄN EI VIITETTÄ TEKSTISSÄ, POISTETAANKO KUN EI VIELÄ JULKAISTU? 
Hofmann, R. (2008). Ownership in learning: A sociocultural perspective on pupil engagement, collaboration and agency in the classroom. Unpublished doctoral dissertation. Faculty of Education, University of Cambridge.

Hofmann, R., \& Rainio, A. P. (2007). "It doesn't matter what part you play, it just matters that you're there." Towards shared agency in narrative play activity in school. In R. Alanen \& S. Pöyhönen (Eds.), Language in action. Vygotsky and Leontievian legacy today (pp. 308-328). Newcastle-upon Tyne: Cambridge Scholars Publishing.

Holland, D., Lachicotte Jr., W., Skinner, D., \& Cain, C. (1998). Identity and agency in cultural worlds. Cambridge, MA: Harvard University Press.

Holzkamp, K. (1991). Societal and individual life processes. Teoksessa C. W. Tolman \& W. Maiers (Toim.), Critical psychology. Contributions to an historical science of the subject (pp. 50-64). Cambridge: Cambridge University Press.

Huf, C. (2013). Children's agency during transition to formal schooling. Ethnography and Education, 8/1, 61-75.

Kant, I. (1803). Über Pädagogik. Retrieved from: http://www2.ibw.uniheidelberg.de/ gerstner/V-Kant_Ueber_Paedagogik.pdf.

Kumpulainen, K., Lipponen, L., Hilppö, J., \& Mikkola, A. (2014). Building on the positive in children's lives: a co-participatory study on the social construction of children's sense of agency. Early Child Development and Care, 184(2), 211-229. TÄHÄN EI VIITETTÄ TEKSTISSÄ, MUT OLIS HYVÄ OLLA: SAATKO LISÄTTY TÄN TEKSTIIN?

Lee, N. (2005). Childhood and Human Value. Open University Press, Buckingham Lindqvist, G. (1995). The Aesthetics of Play. A didactic study of play in preschools. Stockhol: Gotlab.

Lipponen, L., Kumpulainen, K., \& Hilppö. J. (2013). Haluan, voin ja osaan: lasten toimijuuden rakentuminen päiväkodissa. In K. Karila ja L. Lipponen (Eds.), Varhaiskasvatuksen pedagogiikka. Vastapaino: Tampere. [Title in english: I wan to, I can and I know how to: Children's Agency in Kindergarten.] TÄTÄKÄÄN EI TEKSTISSÄ MAINITTU. POIS?

Martin, J. (2004). Self-regulated learning, social cognitive theory, and agency. Educational Psychologist, 39(2), 135-145. 
Marx, K. (1973). Grundrisse: Foundations of the critique of political economy (rough draft). Harmondsworth: Penguin Books.

McNeil, L. M. (1986). Contradictions of control: School structure and school knowledge. New York, London: Routledge.

O’Reilly, K. (2012). Ethnographic methods. 2nd Edition. New York: Routledge.

Prout, A. (2005). The future of childhood. Towards the interdisciplinary study of children. London and New York: RoutledgeFalmer.

Rainio, A. P. (2007). Ghosts, bodyguards and fighting fillies: Manifestations of pupil agency in play pedagogy. ACTIO: International journal for Human Activity Theory, 1, 149-170.

Rainio, A. P. (2008). From resistance to involvement: Examining agency and control in a playworld activity. Mind, Culture, and Activity, 15(2), 115-140.

Rainio, A. P. (2009). Horses, girls, and agency: Gender in play pedagogy. Outlines: Critical Practice Studies, 1, 27-44.

Rainio, A. P. (2010). Lionhearts of the Playworld. An ethnographic case study of the development of agency in play pedagogy. Studies in Educational Sciences 233. Institute of Behavioural Sciences. University of Helsinki.

Rajala, A., Arnold, J., \& Kumpulainen, K. (in preparation). Agency in educational interactions: A special issue. Learning, Culture and Social Interaction. TÄHÄNKÄÄN EI VIITATA

Sainsbury, A. M. (1995). Paradoxes. Cambridge: Cambridge University Press.

Salminen, J. (2012). Koulun pirulliset dilemmat. Helsinki: Teos. [Title in english: The Vexing Dilemmas of Schooling]

St. Pierre, E. A. (2000). Poststructural feminism in education: An overview. Qualitative Studies in Education, 13(5), 477-515.

Tolman, C.W. (1981). The Metaphysic of Relations in Klaus Riegel's 'Dialectic' of Human Development. Human Development, 24, 33-51.

Tolman, C. W. (1994). Psychology, society, and subjectivity. An introduction to German critical psychology. London and New York: Routledge.

Vygotsky, L. S. (1978). Mind in society. The development of the higher psychological processes. Harvard: Harvard University Press. 
Table 1. The dialectics of agency in the playworld

\begin{tabular}{|c|c|c|c|}
\hline $\begin{array}{l}\text { The } \\
\text { dialectics of } \\
\text { agency } \\
\text { between }\end{array}$ & $\begin{array}{l}\text { Theoretical } \\
\text { definition }\end{array}$ & $\begin{array}{l}\text { Manifestation in } \\
\text { Helen and Sara's case }\end{array}$ & $\begin{array}{l}\text { Implications for ethnographic } \\
\text { practice }\end{array}$ \\
\hline $\begin{array}{l}\text { (1) the enacted } \\
\text { and imagined }\end{array}$ & $\begin{array}{l}\text { Agency consists } \\
\text { of both visible } \\
\text { action and of } \\
\text { seemingly } \\
\text { passive } \\
\text { imagining, } \\
\text { dreaming and } \\
\text { escaping. }\end{array}$ & $\begin{array}{l}\text { Sara stayed in the } \\
\text { background throughout } \\
\text { the playworld, and thus } \\
\text { the various fictive } \\
\text { characters she played } \\
\text { went unnoticed by most } \\
\text { of us. On the other } \\
\text { hand, these invisible } \\
\text { roles were inspired by } \\
\text { participation in the } \\
\text { playworld and could } \\
\text { probably exist and } \\
\text { flourish only in these } \\
\text { girls' closed } \\
\text { "microworld." }\end{array}$ & $\begin{array}{l}\text { Observing and analyzing visible } \\
\text { action easily leads away from many } \\
\text { less visible forms of agentic actions } \\
\text { that are not accessible to the } \\
\text { researcher as easily. If this dialectics } \\
\text { is to be depicted, multiple data } \\
\text { collection methods need to be } \\
\text { applied. }\end{array}$ \\
\hline $\begin{array}{l}\text { (2) the } \\
\text { situative and } \\
\text { developmental }\end{array}$ & $\begin{array}{l}\text { Agency is both } \\
\text { situative as well } \\
\text { as gradually } \\
\text { developmental. }\end{array}$ & $\begin{array}{l}\text { The full scope of Helen's } \\
\text { and Sara's agentive actions } \\
\text { within the playworld } \\
\text { became visible only } \\
\text { through closely analyzing } \\
\text { certain micro-interaction } \\
\text { events in relation to a five- } \\
\text { month span of activities. }\end{array}$ & $\begin{array}{l}\text { Depicting this dialectics between } \\
\text { agency as an interactionally } \\
\text { emergent phenomenon and as the } \\
\text { result of longer qualitative } \\
\text { development that becomes visible } \\
\text { only in a longer time scale requires } \\
\text { video recordings for the analysis of } \\
\text { micro-interaction but also time and } \\
\text { investment in the field to depict the } \\
\text { longer time scales. }\end{array}$ \\
\hline $\begin{array}{l}\text { (3) dependence } \\
\text { and separateness }\end{array}$ & $\begin{array}{l}\text { Agency is both } \\
\text { belonging to a } \\
\text { community and } \\
\text { separating from } \\
\text { it. }\end{array}$ & $\begin{array}{l}\text { Although Helen and Sara } \\
\text { longed for recognition in } \\
\text { the playworld, their need } \\
\text { for their own play started } \\
\text { to isolate them from other } \\
\text { children. }\end{array}$ & $\begin{array}{l}\text { The ethnographer interested in children's } \\
\text { agency could benefit from paying } \\
\text { attention to those situations in which } \\
\text { there is a struggle or movement between } \\
\text { belonging and taking distance. }\end{array}$ \\
\hline $\begin{array}{l}\text { (4) mastery and } \\
\text { submission }\end{array}$ & $\begin{array}{l}\text { Agency requires } \\
\text { submitting to } \\
\text { existing cultural } \\
\text { tools and } \\
\text { discourses in } \\
\text { order to master } \\
\text { and alter them. }\end{array}$ & $\begin{array}{l}\text { Helen creatively expanded } \\
\text { her participation in the } \\
\text { playworld by submitting } \\
\text { her horse role to fit its } \\
\text { gendered categories and } \\
\text { practices (the Horse } \\
\text { Soldier). }\end{array}$ & $\begin{array}{l}\text { The ethnographer interested in } \\
\text { children's agency could benefit from } \\
\text { paying attention to those situations } \\
\text { in which the children both creatively } \\
\text { use and master the existing } \\
\text { discourses as well as when they } \\
\text { submit themselves to them in order } \\
\text { to master them. }\end{array}$ \\
\hline
\end{tabular}




\begin{tabular}{|l|l|l|l|}
\hline $\begin{array}{l}\text { (5) control and } \\
\text { freedom }\end{array}$ & $\begin{array}{l}\text { An educator's } \\
\text { support of } \\
\text { children's } \\
\text { agency requires } \\
\text { both embracing } \\
\text { their personal } \\
\text { freedom and } \\
\text { structuring and } \\
\text { limiting it. }\end{array}$ & $\begin{array}{l}\text { Helen and Sara's horse } \\
\text { roles in the playworld } \\
\text { would have needed to be } \\
\text { recognized and supported, } \\
\text { but the structure of the } \\
\text { playworld and the } \\
\text { teachers' preset } \\
\text { pedagogical objectives } \\
\text { made this difficult. At the } \\
\text { same time this freely } \\
\text { structured playworld } \\
\text { enabled these various } \\
\text { positions. }\end{array}$ & $\begin{array}{l}\text { The ethnographer trying to } \\
\text { understand children's agency could } \\
\text { benefit from investigating the } \\
\text { educational practices together with } \\
\text { the practitioners, in order to identify } \\
\text { situations in which this contradiction } \\
\text { is faced, negotiated and sometimes } \\
\text { even overcome. }\end{array}$ \\
& & \\
\hline
\end{tabular}


